\title{
Critical Barriers to Traditional Project Progress Measurement: Perspectives of Ghanaian Construction Professionals
}

\author{
James Cofie Danku1, Kofi Agyekum¹, Francis Terkpertey Asare² \\ ${ }^{1}$ Department of Construction Technology and Management, Kwame Nkrumah University of Science and Technology, \\ Kumasi, Ghana \\ ${ }^{2}$ GCB Bank, Accra, Ghana \\ Email: jmcdanku@yahoo.com
}

How to cite this paper: Danku, J.C., Agyekum, K. and Asare, F.T. (2020) Critical Barriers to Traditional Project Progress Measurement: Perspectives of Ghanaian Construction Professionals. Journal of Building Construction and Planning Research, 8, 119-137.

https://doi.org/10.4236/jbcpr.2020.82008

Received: March 13, 2020

Accepted: May 3, 2020

Published: May 6, 2020

Copyright $\odot 2020$ by author(s) and Scientific Research Publishing Inc. This work is licensed under the Creative Commons Attribution International License (CC BY 4.0).

http://creativecommons.org/licenses/by/4.0/

\begin{abstract}
Accurate project progress measurement is critical for effective project management. Besides guarantying smooth work progress, it affords project managers the chance to identify early warning signs for peremptory remedial actions to keep the project on schedule and to budget. However, pertinent barriers can suppress the realization of the benefits of an accurate assessment of construction progress. This study aims to identify, examine and prioritize the critical barriers militating against accurate project progress measurement in the Ghanaian construction industry. Sixteen barriers identified from the literature were administered in a questionnaire survey to professionals with tier one construction firms and consultants. Sixty experienced construction professionals practising with tier-one construction firms and consultancy services took part in the survey. The relative importance index technique was used to rank the factors and correlation in responses of the two parties tested by the Mann-Whitney $U$ statistics. The most critical barriers perceived by the professionals were 1) Reliance on Supervisor's Judgement, 2) Generic and Non-Systematic Approach, 3) Variable Quality of Data and 4) Intricate Measurement Reports. Other highly ranked barriers include 5) Lack of Timely Information, 6) Laborious Data Gathering and 7) Quality Integration Constraint. The findings underpin the need to minimize dependence on subjective opinions and mere experiences of supervisors for assessment of project progress in this age of information technology. Incorporation of a level of automation into traditional progress methods will not only reduce human errors introduced into manually collected data but facilitate visualization of progress reports. Contiguous to a clear specification of the method of progress measurement in the contract document, a system that conveniently integrates
\end{abstract}


cost, time and scope of work into progress measurement must be pursued. Addressing these identified critical barriers will consolidate current construction progress management practices.

\section{Keywords}

Project Progress Measurement, Critical Barriers, Construction Professionals, Traditional Methods, Ghana

\section{Introduction}

Project progress measurement is one of the cardinal indicators of effective project management. A credible measurement of physical progression during construction phase requires that meticulous attention be paid to the method, structure and accuracy of measurements. For any project to be successful, PMI [1] opined the need for accurate and timely feedback. This will not only afford project managers to identify early warning signs for swift remedial actions to keep it on budget and schedule but also assures one of smooth progression. The traditional project measurement techniques include Cost Ratio, Supervisor's Opinion, Units Completed, Time Ratio and Incremental Milestone. The rest are Start-Finish, Weighted/Equivalent Units and Earned Value Analysis [2] [3] [4]. The realization of the full potential of these methods could be impeded by several factors [5] [6] [7]. Laborious data collection and extraction from contract documents, tedious data calculation, time-consuming, costly, inaccurate and non-controlled at real-time are areas of inhibitions of these traditional methods.

This study aims to identify the barriers associated with traditional construction works progress measurement techniques. Identifying and prioritizing obstacles in the progress measurement system will serve as a panacea for isolating bottlenecks with the view to improving the techniques. Realization of accurate assessment of construction progress will boost productivity by accurately mapping the current state of work vis a vis the budgeted resources and scope of the project. The emerging three-dimensional and four-dimensional progress measurement models, which rely on Global Positioning System, Radio Frequency Identification, Laser Detection and Ranging and Video and Audio Technologies to automatically collect and visualize data at real-time have not been considered here. These automated methods are not covered here because their uses are rare in the Ghanaian construction industry due to the high information technology infrastructure requirement. Factors mitigating against precise progress measurement of construction projects or barriers will be identified from relevant literature and in consultation with professionals in the industry. A survey-based research strategy employing a questionnaire data collection instrument will be adopted. The barriers will then be ranked in order of their impact and based upon construction professionals' perceptions on the level of agreement or disa- 
greement. Correlations of responses will also be tested using statistical MannWhitney $U$ test.

\section{Barriers to Project Progress Measurement}

There are barriers that stifle accurate assessment of construction project progress. These barriers impact negatively on the measurement accuracy, assessment time, cost efficiency, real-time data management and process expediency. Identification and curtailing or isolation of the barriers will strengthen the methods towards the successful delivery of project progress. Sixteen factors inhibiting effective traditional project progress measurement have been identified from literature and interaction with construction professionals. These barriers are presented in Table 1. They include 1) "Lack of Timely Information", 2) "Laborious Data Gathering", 3) "Variable Quality of Data", 4) "Fixation on Time Data" and 5) "Fixation on Cost Data". Others consist of 6) "Intricate Measurement Reports", 7) "Reliance on Supervisor's Judgement", 8) "Quality Integration Constraint" 9) "Generic and Non-systematic Approach" and 10) "Deficient Method Statement". The rest comprise 11) "Frequent Variation in Work", 12) "Contentious Claims", 13) “Unrealistic Planning”, 14) “Unforeseen Site Conditions”, 15) "Extension of Time" and 16) "Delays and Disruptions". These factors are briefly elaborated upon below.

\subsection{Lack of Timely Information}

The traditional methods such as Time Ratio, Incremental Milestone and StartFinish, cannot facilitate real-time progress measurement. They are time-consuming as data is collected manually through on-site monitoring and extensive as-planned and as-built extractions from drawings, schedules, budgets and field reports [5] [9]. According to Cheung et al. [6], the processes are tedious because they do not lend themselves to automation.

\subsection{Laborious Data Gathering}

The methods rely on a great amount of work undertaken manually therefore liable to human-errors which undermine the quality of the end results. Golparvar-Fard et al. [23] concurred by stating that manually acquired data is flawed because it depends upon field staff s interpretation of measurement modalities in terms of what items to be measured and how they can be measured on construction sites. The manual data collection makes the process arduous and inaccurate as it relies on a lot of calculations [7]. From their study, Davidson and Skibniewski [11] concluded that the performance improvement of automatic data collection over manual falls between $400 \%$ to $710 \%$. The excessive amount of work required to be performed may cause human-errors thereby reducing the quality of manually collected data, consequently rendering it ineffective and expensive [13]. There is also the tendency of manual progress assessment being too optimistic due to the human nature of reporting good news. 
Table 1. Typology of barriers to progress measurement of construction projects.

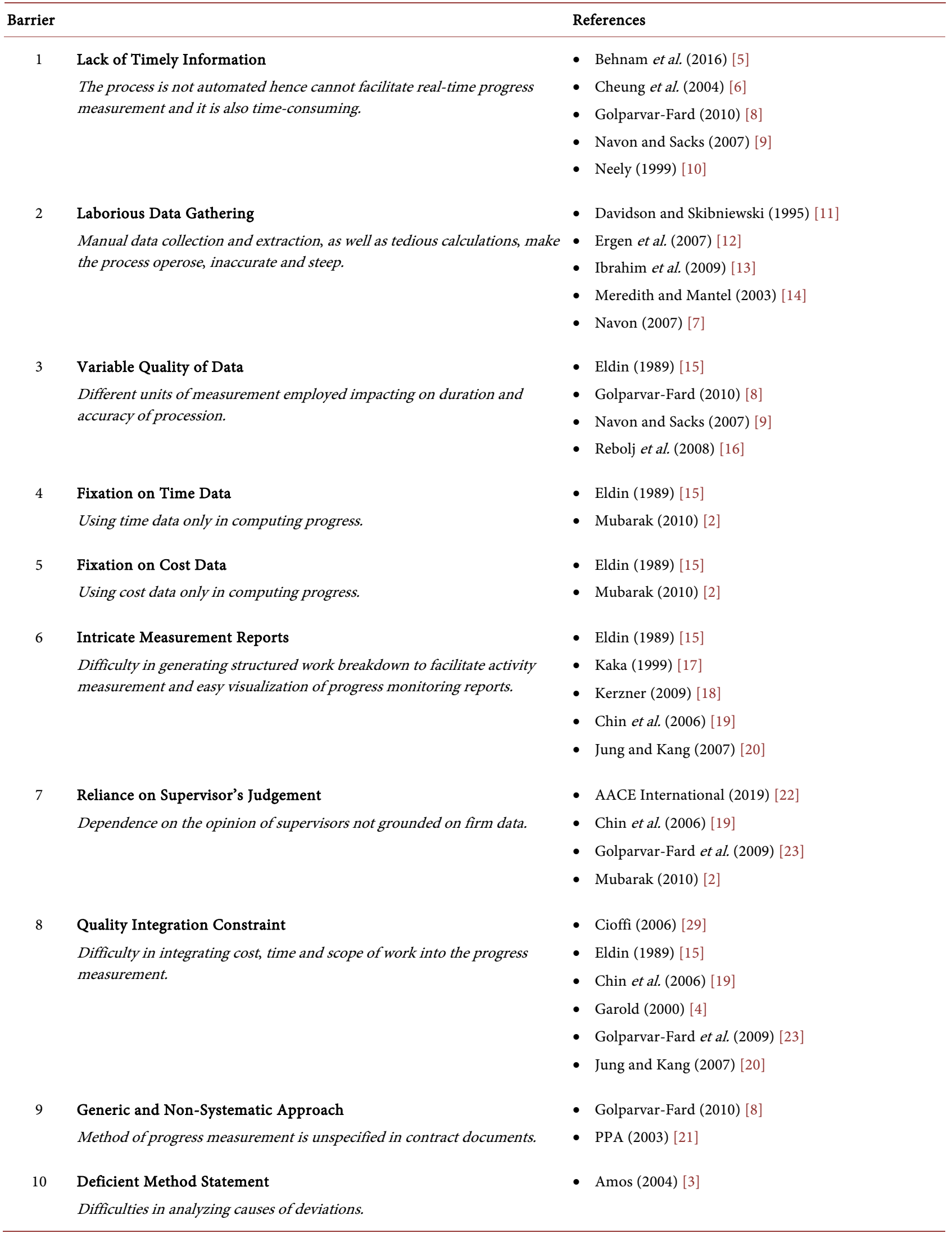




\section{Continued}

\begin{tabular}{|c|c|c|}
\hline \multirow[t]{4}{*}{11} & Frequent Variation in Work & - AACE International (2019) [22] \\
\hline & Changing nature of work necessitating corrective measures. & - $\operatorname{Amos}(2004)[3]$ \\
\hline & & - Mubarak (2010) [2] \\
\hline & & - Neely (1999) [10] \\
\hline \multirow[t]{5}{*}{12} & Contentious Claims & - Abdul-Malak et al. (2002) [24] \\
\hline & Non-defined work scope and responsibilities, and poor documentation. & - Kululanga (2001) [25] \\
\hline & & - Lu et al. (2015) [26] \\
\hline & & - Stamatiou (2019) [27] \\
\hline & & - Vidogah (1998) [28] \\
\hline \multirow[t]{3}{*}{13} & Unrealistic Planning & - Golparvar-Fard (2010) [8] \\
\hline & Inadequate pre-contract planning resulting in increased scope of effort and & • Kerzner (2009) [18] \\
\hline & extensive as-planned data. & - Mubarak (2010) [2] \\
\hline \multirow[t]{2}{*}{14} & Unforeseen Site Conditions & - Garold (2000) [4] \\
\hline & The difficulty in taking physical measurement under inclement weather. & - Yogeswaran et al. (1998) [30] \\
\hline \multirow[t]{2}{*}{15} & Extension of Time & - AACE International (2019) [22] \\
\hline & Measurements related to time are muddled when time changes. & - Mubarak (2010) [2] \\
\hline \multirow[t]{4}{*}{16} & Delays and Disruptions & - AACE International (2019) [22] \\
\hline & Progress measurement becomes distorted whenever work is interrupted and & - Garold (2000) [4] \\
\hline & prolonged reports also delay decision making process. & - Golparvar-Fard et al. (2009) [23] \\
\hline & & - Kaka (1999) [17] \\
\hline
\end{tabular}

\subsection{Variable Quality of Data}

The principle of measuring progress premised on harmonizing the varied units installed or billed quantities towards a unique progress technique can impose a strong barrier which inhibits efficiency [15]. The difficulty of integrating the varied units of the subcomponents into a unique progress measuring method affects the quality of the data. Data is expensive to acquire and additional resources are required to convert from one form into applicable and interpretable progress measurement parameter formats. No doubt, Rebolj et al. [16] intimated that current quality data requirements are low therefore requiring a greater amount of time, cost and effort to meet the necessary information threshold.

\subsection{Fixation on Time Data}

According to Mubarak [2], once a project commences, some aspects can suffer deviations such as overspending, schedule slippage, or a marked departure from the scope of the original work. Progress measurement techniques that rely solely on time as the central assessment criterion does so at the expense of the actual quantity of work executed and cost expended. Any lag, pulse, lead or deviation in time schedule, communicates a distorted and inaccurate position of the works progress. Unless the work is carried out on schedule, according to budget and 
quantity, progress measurement based on time becomes incoherent and unaccepted. In other words, when the project evidently deviates from the budget (over or under) a significant error is introduced into this method.

\subsection{Fixation on Cost Data}

Progress measurement which is centered primarily on only cost assumes that work schedule remains unchanged. This cannot be the case as several factors, including work variations and delays, could alter or affect time. When work is running significantly over or under schedule, inconsistencies and errors are introduced into this progress assessment method. Any extension in time will portray the impression that the work progress is ahead of schedule when cost or budget ratio system is used. Fluctuation in cost can manifest in over or under budgeting, which ultimately bamboozles the work progress assessment technique [2] [15].

\subsection{Intricate Measurement Reports}

According to Golparvar-Fard [8], current progress monitoring reports used in the construction industry are virtually complex. The measurement schedule can be represented in bar graphs, charts, logic diagrams, bubble charts or tables. Kerner [18], asserted that there are more than 30 visual methods for representing activities. It is therefore difficult to produce a targeted progress measurement technique that satisfies the varied needs of the different players in the industry such as in-house management control meetings, technical interchange meetings, customer summary meetings and program review meetings. Koo and Fischer [31] also introduced the limitation of spatial aspects of construction on current progress reports.

\subsection{Reliance on Supervisor's Judgement}

Current progress measurement methods are non-systematic and subjective, declared Golparvar-Fard et al. [23]. Chin et al. [19] acknowledged that the methods are non-effective because they are based on subjective opinion or judgements and diverse criteria, contingent upon one's understanding, experiences and preferences. Depending on the skills, knowledge, experience and ability, the competence of the resultant progress assessment method will vary.

\subsection{Quality Integration Constraint}

A successful project is one completed on time, cost-effective and executed within the scope of work. A measure of the completed work can be compared to that scheduled [29], just as the current cost of work can be assessed in relation to the budgeted cost. The difficulty, however, is the integration of all three quality parameters, i.e. cost, time and scope of work, into the project progress measurement technique. Golparvar-Fard et al. [23] elucidated this by stating that progress reports do not effectually portray the quality multivariable of time, cost 
and performance.

\subsection{Generic and Non-Systematic Approach}

It is not mandatory to specify a method for measuring progress in the contract documents [21]. This flexibility translates into non-systematic and varied unstructured methods employed in progress measurement. When no specific progress method has been envisaged and provided for in the as-planned data, vested interests appropriate the system to suit a specific need or constituency.

\subsection{Unrealistic Planning}

Effective progress measurement thrives on accurate and dependable planning data. A measure of progress becomes incongruous if it is not grounded in a solid benchmark. Any laxity in consistent appraisal of project plan and application of control mechanisms affect the progress assessment. As pointed out by Kerzner [18], inadequate formal planning affects the scope of work and in furtherance the progress assessment.

\subsection{Deficient Method Statement}

Work progress can be assessed readily if standards on how to perform work-related tasks or operate a piece of plant are clearly outlined [3]. This then forms the cardinal base on which the work executed will be assessed. Unrealistic or incomprehensible method statement can serve as a barrier to effective progress measurement.

\subsection{Frequent Variation in Work}

Evaluating the degree to which a construction project is tracking to its schedule and budget affords stakeholders appraisal of the progress. Variations result from poor estimation of resources, errors, omissions, price fluctuation and defects [3] [22]. It can have an impact on the progress measurement due to consequential disparities in schedule, cost and scope of work.

\subsection{Contentious Claims}

Disagreements over extension of time or the rates applicable to varied works are common sources of claim contestations as argued by Abdul-Malak et al. [24]. Unresolved disputes imply a hold-up of the payment [26]. Coupled with the ad hoc manner in which non-defined work scope claims are managed and the difficulty in quantifying certain aspects of claims [28], hinder satisfactory incorporation of data on claims into progress reports. There is a need for continual progress of the work in spite of the incidence of the cause of claim. Ultimately, the rate of progress should be assessed to redeem the time lost to inexcusable delays.

\subsection{Unforeseen Site Conditions}

Any on-site progress data collection is susceptible to vagaries of the weather. 
There are challenges in taking physical measurement under inclement weather. Unforeseen conditions may arise which require measures that have not been provided for in the contract. It is against this milieu that Yogeswaran et al. [30] advised of stating clear specifications in the contract, addressing severe weather conditions and consequential effects hampering progress. The reliance on manual data collection does not also help this course.

\subsection{Extension of Time}

Any progress measurement data based on time becomes disoriented when project durations are extended. When time is extended with no proportionate cost disbursement, a false impression is created of working ahead of schedule. Mubarak [2] and Yogeswaran et al. [30] stated that time extensions should not automatically lead to additional cost.

\subsection{Delays and Disruptions}

For effective progress monitoring, Kaka [17] admonished that progress reports must not only be accurate but ready on time. Golparvar-Fard et al. [23] on their part, observed that current progress methods involve prolonged description and explanation with the tendency to delay the decision making process. Additionally, delays and interruptions of work on-site affect progress data collection [4].

\section{Research Method}

The study was based on a literature review and inputs from construction professionals. Critical barriers militating against the effective use of traditional progress measurements in Ghana were identified and ranked. The descriptive survey approach was adopted, using the questionnaire format [32]. Within a targeted population of construction professionals, tier-one Building Construction Firms and Quantity Surveying Services operating in the Greater Accra Region of Ghana were purposively sampled. Aside from housing the national capital, this region is a hub of construction activities. According to records at the Association of Building and Civil Engineering Contractors of Ghana (ABCECG) and Ghana Institution of Surveys (GhIS), over 50\% of tier-one Building Construction and three-quarters of Quantity Surveying firms are found in the region. While tier-one construction firms have established structures and visibility, the consultancy services were limited to Quantity Surveyors because other professionals rely on their progress information. A total of 16 barriers hampering the effective application of traditional construction progress measurement methods were used in a structured questionnaire addressed to selected professionals. The five-point Likert-style rating scale in which respondents were expected to rate the barriers, based on their degree of agreement to the realization of accurate assessment of construction progress was employed. A scale of 1- "Strongly Disagree", 2-“Disagree", 3-“Undecided", 4-“Agree" and 5-“Strongly Agree" was used. The total numbers of registered tier-one Construction Firms and Quantity Sur- 
veying Services in Greater Accra Region were obtained as 43 and 28, from ABCECG and GhIS respectively. Sets of questionnaires were distributed to all firms through personal visitation, a system recommended by Ahadzie [33], and based on ABCECG and GhIS directories. After two and a half months, 35 tier-one Building Construction Firms and 25 Quantity Surveying Services properly completed and returned the questionnaires, albeit a number of follow-up telephone reminders and further visitations in some instances. Ranking of the sixteen critical barriers in order of professionals' recognition of the impact on effective project progress measurement was realized by the Relative Importance Index technique [34].

The Relative Importance Index was calculated for each factor, based on the relation:

$$
R I I=\sum W /(A * N)
$$

where

$W=$ Weight assigned to each barrier by the respondents;

$A=$ Highest weight (i.e. 5 in this case);

$N=$ the total number of respondents (60).

Mann-Whitney $U$-test [35], a non-parametric alternative to the standard $t$-test, was used to compare differences between the two independent groups (Contractors and Consultants).

Table 2 displays the demographic information of the respondents. It shows Table 2. Demographic information of respondents.

\begin{tabular}{|c|c|c|c|}
\hline Variable & Characteristics & Frequency & Percentage \\
\hline \multirow[t]{3}{*}{ Firm } & Construction firms & 35 & 58.3 \\
\hline & Consultancy services & 25 & 41.7 \\
\hline & Total & 60 & 100.0 \\
\hline \multirow[t]{3}{*}{ Position in Firm } & Senior staff & 33 & 55.0 \\
\hline & Management & 27 & 45.0 \\
\hline & Total & 60 & 100.0 \\
\hline \multirow[t]{6}{*}{ Working Experience } & $1-5$ years & 1 & 1.7 \\
\hline & $6-10$ years & 11 & 18.3 \\
\hline & $11-15$ years & 12 & 20.0 \\
\hline & $16-20$ years & 21 & 35.0 \\
\hline & Above 20 years & 15 & 25.0 \\
\hline & Total & 60 & 100.0 \\
\hline \multirow{4}{*}{$\begin{array}{l}\text { Knowledge in Construction } \\
\text { Project Progress Measurement }\end{array}$} & Intermediate & 2 & 3.3 \\
\hline & Adequate & 27 & 45.0 \\
\hline & Advanced & 31 & 51.7 \\
\hline & Total & 60 & 100.0 \\
\hline
\end{tabular}


that a total of 60 sets of questionnaires out of the 71 distributed, were received and used in the analysis. This high response rate (84.5\%) can be attributed to personal questionnaire distribution system deployed, coupled with the follow-up reminders. Forty-five per cent of respondents hold managerial positions while the remaining number of 33 are senior staff. Over $98 \%$ of respondents had over 5 years of working experience. In fact, $25 \%$ of respondents have been in the industry for over 20 years. Apart from two personnel with an intermediate level of knowledge in construction project progress measurement, the overwhelming 96.7\% had adequate or advanced knowledge. Consequently, the selected respondents possessed the necessary experiences and understanding of the subject matter.

\section{Results}

The sixteen critical barriers identified, and presented in Table 1, were ranked according to their negative impact on the realization of accurate assessment of construction progress as perceived by construction professionals. The Likert's scale of five ordinal measures from 1 to 5 (strongly disagree to strongly agree) was used to rate these barriers according to contractors' and consultants' level of agreement on their impact on progress measurement. The results of the ranking of the barriers to progress measurement are presented in Table 3. The highest-ranked barrier, having an RII of 98 and a mean score of 4.9, was "Reliance on Supervisor's Judgement". "Generic and Non-systematic Approach" and "Variable Quality of Data" closely followed in second and third places with similar RII of 96 and mean of 4.8, separated only by the standard deviations. With an RII of 93.3, the fourth factor is "Intricate Measurement Reports". The next three barriers whose means exceed 4 and RII of 87, 82 and 80.3 are "Lack of Timely Information", "Laborious Data Gathering" and "Quality Integration Constraint" respectively. Between eight and tenth places can be found "Frequency Variation in Work", Unrealistic Planning" and "Deficient Method Statement" having RII of 77, 74.3 and 70.7 respectively. "Extension of Time", "Fixation on Time Data" and "Fixation on Cost Data" followed next. The least ranked barriers that have low means of 2.85, 2.67 and 2.6, and RII of 57, 53.3 and 52 are "Contentious Claims", "Delays and "Disruptions" and "Unforeseen Site Conditions" respectively.

The degree of correlation of the ranking factors (barriers) among the two independent groups of Contractors and Consultants was tested by the MannWhitney $U$ test. This non-parametric test uses ordinal data for relatively small samples [35]. Instead of the standard $t$-test which measures the central tendency by comparing the means, the Mann-Whitney relies on the median (compares the ranks). The results of the Mann-Whitney $U$ test to determine the significant correlation between perceived barriers to progress measurement by contractors and consultants are presented in Table 4 and Table 5. SPSS (Statistical package for social scientists, V 20) was used to produce the tables. From Table 4, it is observed that there is an enormous difference between the Mean Ranks of 
Table 3. Ranking of barriers to progress measurement.

\begin{tabular}{|c|c|c|c|c|c|c|}
\hline Barrier & $N$ & Sum & Mean & $\begin{array}{l}\text { Standard } \\
\text { Deviation }\end{array}$ & RII & Ranking \\
\hline $\begin{array}{l}\text { Reliance on Supervisor's Judgement } \\
\text { Dependence on the opinion of supervisors not grounded on firm data. }\end{array}$ & 60 & 294 & 4.90 & 0.303 & 98.0 & 1 \\
\hline $\begin{array}{l}\text { Generic and Non-systematic Approach } \\
\text { Method of progress measurement is unspecified in contract documents. }\end{array}$ & 60 & 288 & 4.80 & 0.514 & 96.0 & 2 \\
\hline $\begin{array}{l}\text { Variable Quality of Data } \\
\text { Different units of measurement employed impacting on duration and accuracy of } \\
\text { procession. }\end{array}$ & 60 & 288 & 4.80 & 0.546 & 96.0 & 3 \\
\hline $\begin{array}{l}\text { Intricate Measurement Reports } \\
\text { Difficulty in generating structured work breakdown to facilitate activity measurement } \\
\text { and easy visualization of progress monitoring reports. }\end{array}$ & 60 & 280 & 4.67 & 0.510 & 93.3 & 4 \\
\hline $\begin{array}{l}\text { Lack of Timely Information } \\
\text { The process is not automated hence cannot facilitate real-time progress measurement } \\
\text { and it is also time-consuming. }\end{array}$ & 60 & 261 & 4.35 & 0.732 & 87.0 & 5 \\
\hline $\begin{array}{l}\text { Laborious Data Gathering } \\
\text { Manual data collection and extraction, as well as tedious calculations, make the } \\
\text { process operose, inaccurate and steep. }\end{array}$ & 60 & 246 & 4.10 & 0.543 & 82.0 & 6 \\
\hline $\begin{array}{l}\text { Quality Integration Constraint } \\
\text { Difficulty in integrating cost, time and scope of work (quality) into the progress } \\
\text { measurement. }\end{array}$ & 60 & 241 & 4.02 & 0.892 & 80.3 & 7 \\
\hline $\begin{array}{l}\text { Frequent Variation in Work } \\
\text { Changing nature of work necessitating corrective measures. }\end{array}$ & 60 & 231 & 3.85 & 0.659 & 77.0 & 8 \\
\hline $\begin{array}{l}\text { Unrealistic Planning } \\
\text { Inadequate pre-contract planning resulting in increased scope of effort and extensive } \\
\text { as-planned data. }\end{array}$ & 60 & 223 & 3.72 & 0.804 & 74.3 & 9 \\
\hline $\begin{array}{l}\text { Deficient Method Statement } \\
\text { Difficulties in analyzing causes of deviations. }\end{array}$ & 60 & 212 & 3.53 & 0.812 & 70.7 & 10 \\
\hline $\begin{array}{l}\text { Extension of Time } \\
\text { Measurements related to time are muddled when time changes. }\end{array}$ & 60 & 196 & 3.27 & 0.710 & 65.3 & 11 \\
\hline $\begin{array}{l}\text { Fixation on Time Data } \\
\text { Using time data only in computing progress. }\end{array}$ & 60 & 195 & 3.25 & 0.751 & 65.0 & 12 \\
\hline $\begin{array}{l}\text { Fixation on Cost Data } \\
\text { Using cost data only in computing progress. }\end{array}$ & 60 & 195 & 3.25 & 0.751 & 65.0 & 13 \\
\hline $\begin{array}{l}\text { Contentious Claims } \\
\text { Non-defined work scope and responsibilities, and poor documentation. }\end{array}$ & 60 & 171 & 2.85 & 0.954 & 57.0 & 14 \\
\hline $\begin{array}{l}\text { Delays and Disruptions } \\
\text { Progress measurement becomes distorted whenever work is interrupted and } \\
\text { prolonged reports also delay decision making process. }\end{array}$ & 60 & 160 & 2.67 & 1.052 & 53.3 & 15 \\
\hline $\begin{array}{l}\text { Unforeseen Site Conditions } \\
\text { The difficulty in taking physical measurement under inclement weather. }\end{array}$ & 60 & 156 & 2.60 & 0.827 & 52.0 & 16 \\
\hline
\end{tabular}

contractors (40.17) and consultants (16.96) with respect to barrier 1 or "Lack of Timely Information". Similarly, great margins in the Mean Ranks can be detected in barriers 5 (Fixation on Cost Data), 10 (Deficient Method Statement), 12 (Contentious Claims) and 8 (Quality Integration Constraint). "Unforeseen Site Conditions" (barrier 14) has Mean Ranks of 36.23 and 22.48 respectively for 
Table 4. Barriers to progress measurement ranks.

\begin{tabular}{|c|c|c|c|c|c|}
\hline & Barrier & $\begin{array}{l}\text { Category of } \\
\text { Respondents }\end{array}$ & $N$ & $\begin{array}{l}\text { Mean } \\
\text { Rank }\end{array}$ & $\begin{array}{l}\text { Sum } \\
\text { of Ranks }\end{array}$ \\
\hline \multirow[b]{2}{*}{1} & Lack of Timely Information & Contractors & 35 & 40.17 & 1406 \\
\hline & $\begin{array}{l}\text { The process is not automated hence cannot facilitate real-time progress measurement and it } \\
\text { is also time-consuming. }\end{array}$ & $\begin{array}{l}\text { Consultants } \\
\text { Total }\end{array}$ & 25 & 16.96 & 424 \\
\hline \multirow[b]{2}{*}{2} & Laborious Data Gathering & Contractors & 35 & 32.71 & 1145 \\
\hline & $\begin{array}{l}\text { Manual data collection and extraction, as well as tedious calculations, make the process } \\
\text { operose, inaccurate and steep. }\end{array}$ & $\begin{array}{l}\text { Consultants } \\
\text { Total }\end{array}$ & 25 & 27.40 & 685 \\
\hline 3 & $\begin{array}{l}\text { Variable Quality of Data } \\
\text { Different units of measurement employed impacting on duration and accuracy of } \\
\text { procession. }\end{array}$ & $\begin{array}{l}\text { Consultants } \\
\text { Total }\end{array}$ & 35 & 30.04 & 1051.5 \\
\hline 4 & $\begin{array}{l}\text { Fixation on Time Data } \\
\text { Using time data only in computing progress. }\end{array}$ & $\begin{array}{l}\text { Contractors } \\
\text { Consultants } \\
\text { Total }\end{array}$ & $\begin{array}{l}25 \\
60\end{array}$ & $\begin{array}{l}34.50 \\
24.90\end{array}$ & $\begin{array}{l}1207.5 \\
622.5\end{array}$ \\
\hline 5 & $\begin{array}{l}\text { Fixation on Cost Data } \\
\text { Using cost data only in computing progress. }\end{array}$ & $\begin{array}{c}\text { Contractors } \\
\text { Consultants } \\
\text { Total }\end{array}$ & 60 & $\begin{array}{l}34.97 \\
24.24\end{array}$ & $\begin{array}{l}1224 \\
606\end{array}$ \\
\hline 6 & $\begin{array}{l}\text { Intricate Measurement Reports } \\
\text { Difficulty in generating structured work breakdown to facilitate activity measurement and } \\
\text { easy visualization of progress monitoring reports. }\end{array}$ & $\begin{array}{c}\text { Contractors } \\
\text { Consultants } \\
\text { Total }\end{array}$ & 25 & 30.73 & 1075.5 \\
\hline 7 & $\begin{array}{l}\text { Reliance on Supervisor's Judgement } \\
\text { Dependence on the opinion of supervisors not grounded on firm data. }\end{array}$ & $\begin{array}{l}\text { Contractors } \\
\text { Consultants } \\
\text { Total }\end{array}$ & 60 & 27.98 & $\begin{array}{l}1082.5 \\
747.5\end{array}$ \\
\hline 8 & $\begin{array}{l}\text { Quality Integration Constraint } \\
\text { Difficulty in integrating cost, time and scope of work (quality) into the progress } \\
\text { measurement. }\end{array}$ & $\begin{array}{l}\text { Contractors } \\
\text { Consultants } \\
\text { Total }\end{array}$ & 25 & 21.86 & 1065 \\
\hline 9 & $\begin{array}{l}\text { Generic and Non-systematic Approach } \\
\text { Method of progress measurement is unspecified in contract documents. }\end{array}$ & $\begin{array}{l}\text { Contractors } \\
\text { Consultants } \\
\text { Total }\end{array}$ & 25 & 29.90 & 1130.5 \\
\hline 10 & $\begin{array}{l}\text { Deficient Method Statement } \\
\text { Difficulties in analyzing causes of deviations. }\end{array}$ & $\begin{array}{l}\text { Contractors } \\
\text { Consultants }\end{array}$ & 60 & $\begin{array}{l}38.09 \\
19.88\end{array}$ & 1333 \\
\hline 11 & $\begin{array}{l}\text { Frequent Variation in Work } \\
\text { Changing nature of work necessitating corrective measures }\end{array}$ & $\begin{array}{l}\text { Contractors } \\
\text { Consultants } \\
\text { Total }\end{array}$ & 25 & 26.28 & 1173 \\
\hline 12 & $\begin{array}{l}\text { Contentious Claims } \\
\text { Non-defined work scope and responsibilities, and poor documentation. }\end{array}$ & $\begin{array}{c}\text { Contractors } \\
\text { Consultants } \\
\text { Total }\end{array}$ & 25 & 21.80 & 1060 \\
\hline
\end{tabular}




\section{Continued}

Unrealistic Planning

13 Inadequate pre-contract planning resulting in increased scope of effort and extensive as-planned data

14

Unforeseen Site Conditions

The difficulty in taking physical measurement under inclement weather.

15

Extension of Time

Measurements related to time are muddled when time changes.

Delays and Disruptions

16 Progress measurement becomes distorted whenever work is interrupted and prolonged reports also delay decision making process.

\begin{tabular}{llll} 
Contractors & 35 & 36.71 & 1285 \\
Consultants & 25 & 42.60 & 545 \\
$\quad$ Total & 60 & & \\
Contractors & 35 & 36.23 & 1268 \\
Consultants & 25 & 22.48 & 562 \\
$\quad$ Total & 60 & & \\
Contractors & 35 & 30.30 & 1060.5 \\
Consultants & 25 & 30.78 & 769.5 \\
$\quad$ Total & 60 & & \\
Contractors & 35 & 27.41 & 959.5 \\
Consultants & 25 & 34.82 & 870.5 \\
$\quad$ Total & 60 & & \\
\hline
\end{tabular}

Contractors and Consultants. At the other end of the spectrum are those barriers with close or similar Mean Ranks. For example, the Mean Ranks of Contractors and Consultants for "Variable Quality of Data" (barrier 3 in Table 4) are 30.04 and 31.14 respectively. Similar close results of 30.73 and 30.18 apply to "Intricate Measurement Reports" (barrier 6) and "Extension of Time" (contractors-30.30, consultants-30.78). A significant difference in the Mean Rank scores between the Contractors and Consultants in relation to a barrier indicates divergence. When the two groups agree on a barrier to an extent, the difference in their mean Ranks is negligible or very small.

From Table 5, it can be observed that the Mann-Whitney $U$ value of 99 for barrier 1 (Lack of Timely Information) is very small. Other factors with relatively small values include "Fixation on Cost Data" (barrier 5), "Deficient Method Statement" (barrier 10), "Contentious Claims" (barrier 12) and "Quality Integration Constraint" (barrier 13) with values 281,172,140 and 135 respectively. Another barrier having a low Mann-Whitney $U$ value of 237 is "Unforeseen Site Conditions". There are some barriers with relatively high Mann-Whitney values too. "Variable Quality of Data" (421.5), "Intricate Measurement Reports" (429.5), "Reliance on Supervisor's Judgement" (422.5)", "Generic and Non-systematic Approach" (374.5) and "Extension of Time" (430.5), corresponding to barriers 3, 6, 7, 9 and 15 can be cited. In general, small Mann-Whitney $U$ values are indicative of divergence in the responses of Contractors and Consultants. In contrast, when there is a convergence of thoughts on a particular barrier by the two parties, a relatively large Mann-Whitney $U$ score emanates.

\section{Discussion}

Units Completed, Cost Ratio, Time Ratio and Start-Finish are some traditional progress measurement methods employed in the Ghanaian construction industry. The rest include Supervisor's Opinion, Incremental Milestone, Weighted/ 
Table 5. Barriers to progress measurement-test statistics.

\begin{tabular}{|c|c|c|c|c|c|}
\hline & Barrier & $\begin{array}{l}\text { Mann- } \\
\text { Whitney } U\end{array}$ & $\begin{array}{l}\text { Wilcox } \\
\text { on W }\end{array}$ & Z & $\begin{array}{l}\text { Asymptotic } \\
\text { Significance } \\
\text { (2-tailed) }\end{array}$ \\
\hline 1 & $\begin{array}{l}\text { Lack of Timely Information } \\
\text { The process is not automated hence cannot facilitate real-time progress measurement and it is } \\
\text { also time-consuming. }\end{array}$ & 99 & 424 & -5.597 & 0.000 \\
\hline 2 & $\begin{array}{l}\text { Laborious Data Gathering } \\
\text { Manual data collection and extraction, as well as tedious calculations, make the process } \\
\text { operose, inaccurate and steep. }\end{array}$ & 360 & 685 & -1.536 & 0.124 \\
\hline 3 & $\begin{array}{l}\text { Variable Quality of Data } \\
\text { Different units of measurement employed impacting on duration and accuracy of procession. }\end{array}$ & 421.5 & 1051.5 & -0.406 & 0.684 \\
\hline 4 & $\begin{array}{l}\text { Fixation on Time Data } \\
\text { Using time data only in computing progress. }\end{array}$ & 297.5 & 622.5 & -2.281 & 0.023 \\
\hline 5 & $\begin{array}{l}\text { Fixation on Cost Data } \\
\text { Using cost data only in computing progress. }\end{array}$ & 281 & 606 & -2.550 & 0.011 \\
\hline 6 & $\begin{array}{l}\text { Intricate Measurement Reports } \\
\text { Difficulty in generating structured work breakdown to facilitate activity measurement and } \\
\text { easy visualization of progress monitoring reports. }\end{array}$ & 429.5 & 754.5 & -0.148 & 0.882 \\
\hline 7 & $\begin{array}{l}\text { Reliance on Supervisor's Judgement } \\
\text { Dependence on the opinion of supervisors not grounded on firm data. }\end{array}$ & 4225 & 747.5 & -0.433 & 0.665 \\
\hline 8 & $\begin{array}{l}\text { Quality Integration Constraint } \\
\text { Difficulty in integrating cost, time and scope of work (quality) into the progress measurement. }\end{array}$ & 135 & 765 & -4.864 & 0.000 \\
\hline 9 & $\begin{array}{l}\text { Generic and Non-systematic Approach } \\
\text { Method of progress measurement is unspecified in contract documents. }\end{array}$ & 374.5 & 699.5 & -1.523 & 0.128 \\
\hline 10 & $\begin{array}{l}\text { Deficient Method Statement } \\
\text { Difficulties in analyzing causes of deviations. }\end{array}$ & 172 & 497 & -4.709 & 0.000 \\
\hline 11 & $\begin{array}{l}\text { Frequent Variation in Work } \\
\text { Changing nature of work necessitating corrective measures. }\end{array}$ & 332 & 657 & -2.198 & 0.028 \\
\hline 12 & $\begin{array}{l}\text { Contentious Claims } \\
\text { Non-defined work scope and responsibilities, and poor documentations. }\end{array}$ & 140 & 770 & -4.740 & 0.000 \\
\hline 13 & $\begin{array}{l}\text { Unrealistic Planning } \\
\text { Inadequate pre-contract planning resulting in increased scope of effort and extensive } \\
\text { as-planned data. }\end{array}$ & 220 & 545 & -3.791 & 0.000 \\
\hline 14 & $\begin{array}{l}\text { Unforeseen Site Conditions } \\
\text { The difficulty in taking physical measurement under inclement weather. }\end{array}$ & 237 & 562 & -3.268 & 0.001 \\
\hline 15 & $\begin{array}{l}\text { Extension of Time } \\
\text { Measurements related to time are muddled when time changes. }\end{array}$ & 430.5 & 1060.5 & -0.119 & 0.905 \\
\hline 16 & $\begin{array}{l}\text { Delays and Disruptions } \\
\text { Progress measurement becomes distorted whenever work is interrupted and prolonged } \\
\text { reports also delay decision making process. }\end{array}$ & 329.5 & 959.5 & -1.702 & 0.089 \\
\hline
\end{tabular}

${ }^{a}$ Grouping Variable: Category of respondents.

Equivalent Units and Earned Value Analysis. There are challenges or barriers associated with the application of these techniques. Sixteen barriers were identified and presented in Table 1. Sixty Professionals with Construction Firms and Consultancy Services rated these barriers. The perceptions of these professionals 
of the barriers to the accurate progress measurement of construction works were ranked by the RII technique (Table 3). The highest-ranked critical barrier with an RII of 98 was the "Reliance on Supervisor's Judgement". A high mean score of 4.9 is an indication of the overwhelming endorsement of the "strongly agree" affirmation of the 60 respondents. Dependence on subjective opinions and experiences of supervisors for assessment of project progress is not only flawed and unreliable but leaves much to be desired in the present information technology dispensation. It is not therefore surprising that the two independent groups (contractors and consultants) strongly agreed on this factor. Their close-knitted Mean Ranks at 30.93 and 29.90 (Table 4) for Contractors and Consultants respectively, confirms this correlation. A position supported too by the high Mann-Whitney $U$ value of 422.5 (Table 5). The barriers of "Generic and Nonsystematic Approach" and "Variable Quality of Data" followed in second and third places, separated only by the lower standard deviation of the former. The "Generic and Non-systematic Approach' barrier may allow for non-systematic and use of unstructured methods while "Variable Quality Data" poses the difficulty of integrating of varied units of the subcomponents into a unique progress measuring method. Their close Mean Ranks of 30.04 (Contractors) and 31.14 (Consultants), and 32.30 (Contractors) and 27.98 (Consultants) respectively, coupled with the high Mann-Whitney $U$ values of 421.5 and 374.5 demonstrate parallel ratings of these barriers. Highly ranked at the fourth position with RII of 93.3 and Mean Score of 4.67 is the barrier of "Intricate Measurement Reports". The professionals affirmed with Mean Ranks of 30.73 (Contractors) and 30.18 (Consultants), backed by 429.5 Mann-Whitney $U$ value, that difficulty of generating appropriate breakdown of work for facilitation of activity measurement and easy visualization of progress reports (Intricate Measurement Reports) is a critical barrier.

The $5^{\text {th }}$-ranked barrier is "Lack of Timely Information" (RII-87). The contention here is not that it should have been ranked higher but the disparity in correlation between the two groups. The rather low Mann-Whitney $U$ value of 99 shows a great divergence of the two professional groups; while the Contractors scored a high Mean Rank of 40.17, the Consultants only had 16.98. The high difference in their Mean Ranks, with associated low Mann-Whitney, present discord between their ratings. In fact, Contractors perceived this as a greater barrier than consultants. The next order of ranking follows "Laborious Data Gathering", "Quality Integration Constraint", "Frequent Variation in Work" and "Unrealistic Planning". Apart from "Quality Integration Constraint" where the two groups dissent in rating (low Mann-Whitney $U$ of 135 and marked difference in Mean Ranks of 21.86 and 42.60), there is a reasonable correlation within the rest. The least ranked barriers, all of which had means less than 3, are "Contentious Claims", "Delays and Disruptions" and "Unforeseen Site Conditions". Contractors and Consultants did not agree completely on the $14^{\text {th }}$ position of "Contentious Claims" (140 Mann-Whitney $U$ value). Its low ranking by Contrac- 
tors, in particular, is surprising. "Unforeseen Site Conditions", had an RII of just 52 and Mean score of 2.6 to place bottom of the log. It is abstruse to comprehend why construction professionals lowly perceived inclement weather as a critical barrier.

\section{Conclusion}

A prerequisite for holistically addressing an issue or improving upon a system is to identify and isolate any barriers cladding its efficient operation. In light of this, sixteen critical barriers to the realization of accurate construction progress measurement were identified from literature and interaction with construction professionals. They include "Lack of Timely Information", "Laborious Data Gathering", "Variable Quality of Data", "Fixation on Time Data", "Intricate Measurement Reports", "Reliance on Supervisor's Judgement" and "Quality Integration Constraint". "Generic and Non-systematic Approach", "Unrealistic Planning", "Frequent Variation in Work" and "Unforeseen Site Conditions" are some of the Contractual factors. These critical barriers were ranked by the RII technique and "Reliance on Supervisor's Judgement" emerged premium. The next three top-ranked barriers are "Generic and Non-systematic Approach", "Variable Quality of Data" and "Intricate Measurement Reports". Both contractors and consultants collaborated these four peak barriers as evidenced in their high Mann-Whitney $U$ values, coupled with minimal differences in their Mean Ranks. To improve the traditional project progress assessment techniques for effective and productive construction works, particular attention should be focused on these barriers. For example, an automation approach can be introduced to minimize human subjectivity and judgement. There is the need for structured work breakdown to facilitate activity measurement and visualization, in addition to prior specification of any explicit progress measurement method in the contract. Other relevant barriers affecting accurate progress measurement are "Lack of Timely Information", "Laborious Data Gathering”, Quality Integration constraint" and "Frequent Variation in Work" ranked from fifth to eighth. There was congruence in responses of contractors and consultants regarding these barriers except "Lack of timely Information" where there was a great disparity. The least ranked factor is the "Unforeseen Site Conditions". Tied to this are "Contentious Claims" and "Delays and Disruptions", where the professionals perceived them as non-critical barriers to effective project progress measurement. These findings are expected to contribute to the consolidation of construction progress measurement practices through appraisal and addressing of the critical barriers for improved construction industry performance.

\section{Acknowledgements}

The data for this paper were sourced with the kind compliments of the Association of Building and Civil Engineering Contractors of Ghana (ABCECG) and the Ghana Institution of Surveyors (GhIS). The authors express their gratitude to 
the two associations.

\section{Conflicts of Interest}

The authors declare no conflicts of interest regarding the publication of this paper.

\section{References}

[1] PMI (2005) Practice Standard for Earned Value Management. Management Institute, Newtown Square, Newtown Square, PA.

[2] Mubarak, S. (2010) Construction Project Scheduling and Control. 2nd Edition, John Wiley \& Sons Inc., Hoboken, NJ. https://doi.org/10.1002/9780470912171

[3] Amos S.J. (2004) Skills and Knowledge of Cost Engineering. 5th Edition, AACE International. AACE Education Fund, WV.

https://www.academia.edu/33659523/Skills and knowledge of cost engineering

[4] Garold, D.O. (2000) Project Management for Engineering and Construction. 2nd Edition, McGraw Hill, International Edition, Singapore.

[5] Behnam, A., Wickramasinghe, D.C., Ghaffar, M.A.A., Vu, T.T., Tang, Y.H. and Bin Isa, H. (2016) Automated Progress Monitoring System for Linear Infrastructure Projects Using Satellite Remote Sensing. Automation in Construction, 68, 114-127. https://doi.org/10.1016/j.autcon.2016.05.002

[6] Cheung, S.O., Suen, H.C.H. and Cheung, K.K.W. (2004) PPMS: A Web-Based Construction Project Performance Monitoring System. Automation in Construction, 13, 361-376. https://doi.org/10.1016/j.autcon.2003.12.001

[7] Navon, R. (2007) Research in Automated Measurement of Project Performance Indicators. Automation in Construction, 16, 176-188.

https://www.sciencedirect.com/science/article/abs/pii/S0926580506000136 https://doi.org/10.1016/j.autcon.2006.03.003

[8] Golparvar-Fard, M. (2010) D AR-4 Dimensional Augmented Reality-Models for Automation and Interactive Visualization of Construction Progress Monitoring. PhD Dissertation Submitted to the Graduate College of the University of Illinois, Urbana-Champaign, IL.

[9] Navon, R. and Sacks, R. (2007) Assessing Research in Automated Project Performance Control (APPC). Journal of Automation in Construction, 16, 474-484. https://doi.org/10.1016/j.autcon.2006.08.001

[10] Neely, A. (1999) The Performance Assessment Revolution: Why Now and What Next? International Journal of Operations and Production Management, 19, 205-208. https://doi.org/10.1108/01443579910247437

[11] Davidson, I.N. and Skibniewski, M.J. (1995) Simulation of Automated Data Collection in Buildings. Journal of Computing in Civil Engineering, 9, 9-20.

https://doi.org/10.1061/(ASCE)0887-3801(1995)9:1(9)

[12] Ergen, E., Akinci, B. and Sacks, R. (2007). Life-Cycle Data Management of Engineered-to-Order Components Using Radio Frequency Identification. Advanced Engineering Informatics, 21, 356-366. https://doi.org/10.1016/j.aei.2006.09.004

[13] Ibrahim, Y.M., Lukins, T.C., Zhang, X., Trucco, E. and Kaka, A.P. (2009) Towards Automated Progress Assessment of Workpackage Components in Construction Projects using Computer Vision. Advanced Engineering Informatics, 23, 93-103. https://www.sciencedirect.com/science/article/abs/pii/S1474034608000591 
https://doi.org/10.1016/j.aei.2008.07.002

[14] Meredith, J.R. and Mantel Jr., S.J. (2003) Project Management: A Managerial Approach. Fifth Edition, John Wiley and Sons Inc., Hoboken, NJ.

[15] Eldin, N.N. (1989) Measurement of Work Progress: Quantitative Technique. Journal of Construction Engineering and Management, 115, 462-474. https://doi.org/10.1061/(ASCE)0733-9364(1989)115:3(462)

[16] Rebolj, D., Cus Babic, N., Magdic, A., Podbreznik, P. and Psunder, M. (2008) Automated Construction Activity Monitoring System. Advanced Engineering Informatics, 22, 493-503. https://doi.org/10.1016/j.aei.2008.06.002

[17] Kaka, A.P. (1999) The Development of a Benchmark Model that Uses Historical Data for Monitoring the Progress of Current Construction Projects. Engineering, Construction and Architectural Management, 6, 256-266. https://doi.org/10.1108/eb021116

[18] Kerzner, H. (2009) Project Management: A Systems Approach to Planning, Scheduling, and Controlling. 10th Edition, John Wiley \& Sons Inc., Hoboken, NJ.

[19] Chin, S., Yoon, S., Kim, Y.-S., Jung, Y., Park, S.-C. and Chung, M. (2006) A Project Progress Measurement and Management System. Journal of Construction Engineering and Management, 132, No. 4. https://www.irbnet.de/daten/iconda/CIB13684.pdf

[20] Jung, Y. and Kang, S. (2007) Knowledge-Based Standard Progress Measurement for Integrated Cost and Schedule Performance Control. Journal of Construction Engineering and Management, 133, 10-21. https://doi.org/10.1061/(ASCE)0733-9364(2007)133:1(10)

[21] PPA (2003) Ghana Public Procurement Act, Act 663. Public Procurement Board, Accra Ghana. https://www.ppaghana.org/documents/PublicProcurementAct2003Act663.pdf

[22] AACE International (2019) Cost Engineering Terminology. TCM Framework: General Reference. AACE International Recommended Practice No 10S-90. http://www.aacei.org/docs/default-source/rps/10s-90.pdf?sfvrsn $=42$

[23] Golparvar-Fard, M., Pena-Mora, F. and Savarese, S. (2009) Application of D AR A 4-Dimensional Augmented Reality Model for Automating Construction Progress Monitoring Data Collection, Processing and Communication. Journal of Information Technology in Construction, 14, 129-153. http://www.itcon.org/2009/13

[24] Abdul-Malak, M.A.U., El-Saadi, M.M. and Abou-Zeid, M.G. (2002) Process Model for Administrating Construction Claims. Journal of Management and Engineering, 18, 84-94. https://doi.org/10.1061/(ASCE)0742-597X(2002)18:2(84)

[25] Kululanga, G.K., Kuotcha, W., McCaffer, R. and Edum-Fotwe, F. (2001) Construction Contractors' Claim Process Framework. Journal of Construction Engineering and Management, 127, 309-314. https://doi.org/10.1061/(ASCE)0733-9364(2001)127:4(309)

[26] Lu, W., Zhang, L. and Pan, J. (2015) Identification and Analyses of Hidden Transaction Costs in Project Dispute Resolutions. International Journal of Project Management, 33, 711-718. https://doi.org/10.1016/j.ijproman.2014.08.009

[27] Stamatiou, D.R.I., Kirytopoulos, K.A., Ponis S.T., Sotiris Gayialis, S. and Tatsiopoulos, I. (2019) A Process Reference Model for Claims Management in Construction Supply Chains: The Contractors' Perspective. International Journal of Construction Management, 19, 382-400. https://doi.org/10.1080/15623599.2018.1452100

[28] Vidogah, W. and Ndekugri, I. (1998) Improving the Management of Claims on Con- 
struction Contracts: Consultant's Perspective. Construction Management \& Economics, 16, 363-372. https://doi.org/10.1080/014461998372385

[29] Cioffi, D.F. (2006) Designing Project Management: A Scientific Notation and an Improved Formalism for Earned Value Calculations. International Journal of Project Management, 24, 136-144. https://doi.org/10.1016/j.ijproman.2005.07.003

[30] Yogeswaran, K., Kumaraswamy, M.M. and Miller, D.R.A. (1998) Claims for Extensions of Time in Civil Engineering Projects. Construction Management \& Economics, 16, 283-293. https://doi.org/10.1080/014461998372312

[31] Koo, B. and Fischer, M. (2000) Feasibility Study of 4D CAD in Commercial Construction. Journal of Construction Engineering and Management, 126, 251-260. https://doi.org/10.1061/(ASCE)0733-9364(2000)126:4(251)

[32] Gill, J. and Johnson, P. (2002) Research Methods for Managers. Third Edition, Sage Publications Ltd., New York.

[33] Ahadzie, D.K. (2007) A Model for Predicting the Performance of Project Managers in Mass House Building Projects in Ghana. University of Wolverhampton, UK.

[34] Gunduz, M., Nielsen, Y. and Ozdemir, M. (2013) Quantification of Delay Factors Using the Relative Importance Index Method for Construction Projects in Turkey. Journal of Management in Engineering, 29, 133-139.

[35] Arthur, A., Elliot, J.C. and Elaine, N.A. (2013) Statistics for Psychology. Sixth Edition, Pearson Education Limited, Upper Saddle River, NJ.

https://doi.org/10.1061/(ASCE)ME.1943-5479.0000129 